February 2005 - NREL/CP-520-36527

\title{
Trust But Verify: Procedures to Achieve Accurate Efficiency Measurements for All Photovoltaic Technologies
}

\author{
K. Emery, A. Anderberg, J. Kiehl, C. Mack, \\ T. Moriarty, S. Rummel, and L. Ottoson
}

Prepared for the $31^{\text {st }}$ IEEE Photovoltaics Specialists Conference and Exhibition

Lake Buena Vista, Florida January 3-7, 2005
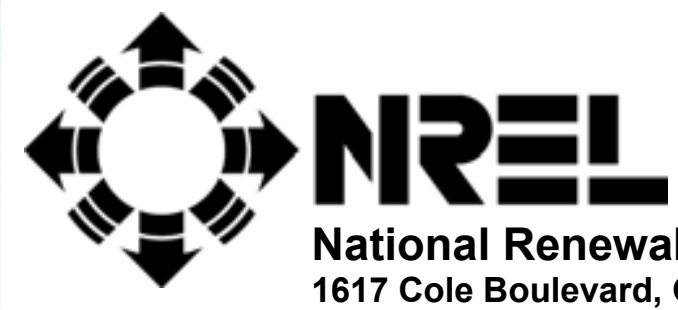

National Renewable Energy Laboratory 1617 Cole Boulevard, Golden, Colorado 80401-3393 303-275-3000 • www.nrel.gov

Operated for the U.S. Department of Energy

Office of Energy Efficiency and Renewable Energy

by Midwest Research Institute $\bullet$ Battelle 


\section{NOTICE}

The submitted manuscript has been offered by an employee of the Midwest Research Institute (MRI), a contractor of the US Government under Contract No. DE-AC36-99G010337. Accordingly, the US Government and MRI retain a nonexclusive royalty-free license to publish or reproduce the published form of this contribution, or allow others to do so, for US Government purposes.

This report was prepared as an account of work sponsored by an agency of the United States government. Neither the United States government nor any agency thereof, nor any of their employees, makes any warranty, express or implied, or assumes any legal liability or responsibility for the accuracy, completeness, or usefulness of any information, apparatus, product, or process disclosed, or represents that its use would not infringe privately owned rights. Reference herein to any specific commercial product, process, or service by trade name, trademark, manufacturer, or otherwise does not necessarily constitute or imply its endorsement, recommendation, or favoring by the United States government or any agency thereof. The views and opinions of authors expressed herein do not necessarily state or reflect those of the United States government or any agency thereof.

Available electronically at http://www.osti.gov/bridge

Available for a processing fee to U.S. Department of Energy and its contractors, in paper, from:

U.S. Department of Energy

Office of Scientific and Technical Information

P.O. Box 62

Oak Ridge, TN 37831-0062

phone: 865.576 .8401

fax: 865.576.5728

email: mailto:reports@adonis.osti.gov

Available for sale to the public, in paper, from:

U.S. Department of Commerce

National Technical Information Service

5285 Port Royal Road

Springfield, VA 22161

phone: 800.553 .6847

fax: 703.605.6900

email: orders@ntis.fedworld.gov

online ordering: http://www.ntis.gov/ordering.htm 


\title{
TRUST BUT VERIFY: PROCEDURES TO ACHIEVE ACCURATE EFFICIENCY MEASUREMENTS FOR ALL PHOTOVOLTAIC TECHNOLOGIES
}

\author{
K. Emery, A. Anderberg, J. Kiehl, C. Mack, T. Moriarty, S. Rummel, and L. Ottoson \\ National Renewable Energy Laboratory (NREL), Golden, CO 80401
}

\begin{abstract}
The measurement of the photovoltaic (PV) performance with respect to reference conditions requires measuring the performance with respect to a given tabular reference spectrum, junction temperature, and total irradiance. This paper discusses the procedures implemented by NREL's PV Cell and Module Performance Characterization Group to achieve the lowest practical uncertainty. This paper describes the process of trusting and verifying software, hardware, calibrations, procedures, and results. As an ISO 17025 accredited calibration facility, the quality system that is in place is designed to assure customers that the results are valid within specified uncertainty limits and are traceable. The process of trusting claims but desiring an independent verification permeates the PV business and society.
\end{abstract}

\section{INTRODUCTION}

The phrase "Trust but Verify" was popular during the Strategic Arm's Limitation Talks in the 1980s, where the United States and Soviet Union trusted each other but required continuous unattended monitoring for compliance with treaty obligations. In the scientific community, the peer review process is critical to verify the quality of a manuscript. Errata and letters to the editor allow results to be challenged and defended. All laboratories must trust some other laboratory for at least part of their calibration traceability path for instruments that report a result. The level of trust that one has in a calibration depends on the laboratory's stature as a national calibration facility (e.g., AIST, NIST, or PTB), an ISO 17025 accredited calibration laboratory, the original equipment manufacturer, or a national laboratory, such as NREL [1]. National standards laboratories and ISO 17025 accredited calibration laboratories have the highest stature because of the rigor in their procedures-a verified quality system.

The same "trust but verify" axiom is applicable to the Photovoltaic Cell and Module Performance Characterization Group at NREL, where our primary function is verifying the performance of PV devices. The group must rely on others for all of their instrumentation and detector radiometer calibrations. Most groups will trust that their equipment is in calibration or calibrated properly. ISO 17025 requires that these calibrations be performed by a national standards facility such as NIST or an ISO 17025 accredited laboratory. One of the key requirements is that these laboratories must demonstrate their proficiency though periodic intercomparisons. NREL has participated in numerous formal [2-6] and informal intercomparisons over the years. This is an ongoing process where, at any point, an intercomparison could reveal differences outside of estimated uncertainty limits. When this occurs, a detailed uncertainty analysis of both groups' methods often reconciles differences.

\section{CELL CALIBRATION}

Since the mid 1980s, there has been a consensus in the PV community for the reference spectrum, total irradiance, temperature, and area definition for flat-plate cells and modules. The journal Progress in Photovoltaics lists record $\mathrm{PV}$ cells and modules that have had independent efficiency verification by a PV calibration laboratory [7]. These tables give the community an alternative to trusting reported record efficiencies for a given technology. There has not been a consensus for rating concentrator cells or modules, and very limited domestic or international characterization standards exist. By default, the concentrator efficiency tables in ref. [7] use the ASTM direct reference spectrum [8]. A more realistic reference spectrum for concentrators is being considered [9]. This version is now an ASTM standard [10] and is being considered as a new IEC global and direct reference spectrum. It has been informally agreed among the PV calibration laboratories to switch to the new spectrum at the same time to minimize confusion.

International PV standards groups have been unable to agree on an acceptable primary terrestrial and extraterrestrial calibration procedure. Each country felt that their methods were the most appropriate or best $[5,6]$. The terrestrial PV community attempted to reconcile this by adopting the world photovoltaic scale, where the values are traceable to three or more laboratories whose primary calibration value was within $1 \%[6,11]$. In the context of this discussion, a primary reference cell is a cell that is not traceable to any other reference cell and is calibrated with SI traceable instrumentation. The extraterrestrial community decided to incorporate all methods in the standard with a distinction between high-altitude / space-based methods and ground-based or synthetic calibration methods [12].

The "trust but verify" axiom has proved critical in determining what is the correct reference spectrum. All published versions of the currently accepted terrestrial reference spectrum have typographical errors in their tables [13]. A more serious example occurred where the tabular AM0 reference spectrum [14] was different than the values published in the standard [15] that it reprinted with permis- 
sion. This occurred because the shepherd for the standard had released a preliminary electronic version, but never sent a final electronic version of the tabular reference spectrum; the electronic values were never checked against the published values in ref. [15]. The wavelength values are all correct, the spectrum integrates to the correct value, and the shape is approximately correct. This mistake propagated to another group at NREL that also received the same early version and had it posted on their Web site from October 1999 to September 2004. In this case, everyone trusted the value, and only cursory verification occurred. In investigating this, it was discovered that the final values submitted to the ASTM committee for adoption and the actual published version differed by two digits out of 14,084 digits in the AM0 table [15]. At 260.5 $\mathrm{nm}$, the AM0 spectral irradiance that was submitted was $85.51 \mathrm{Wm}^{-2} \mathrm{\mu m}^{-1}$, whereas the published value was 88.51 . And at $540.5 \mathrm{~nm}$, the submitted value was 1769 , whereas the published value was $1760 \mathrm{Wm}^{-2} \mu \mathrm{m}^{-1}$ [15]. Which values are correct?

Intercomparisons among terrestrial samples have shown an agreement of $\pm 1 \%$ in the primary reference cell calibration value for $\mathrm{Si}[2,4-6]$. Intercomparisons among AM0 calibration laboratories in the primary reference cell calibration value have shown agreement within $\pm 2 \%$ for terrestrial (synthetic) calibrations and better than $\pm 1 \%$ for aircraft- or balloon-based calibrations [16].

Differences in what is called the area is still a major source of difference, even though the definition has been standardized [17]. These differences can come from a variety of sources, with light piping, poor isolation, and small samples with irregular sides being the most common sources of differences. In some cases, an aperture may be required to establish a well-defined area. Fortunately, the national PV calibration laboratories and the Progress in Photovoltaics efficiency table authors are in agreement [7].

\section{MEASUREMENT TEST BEDS}

All equipment producing a numerical result must be calibrated. The calibration traceability path for standardized cell and module measurements performed at NREL is shown in Fig. 1. Having well-calibrated equipment is not sufficient to ensure accurate measurements because calibrations can drift between the typical one-year calibration

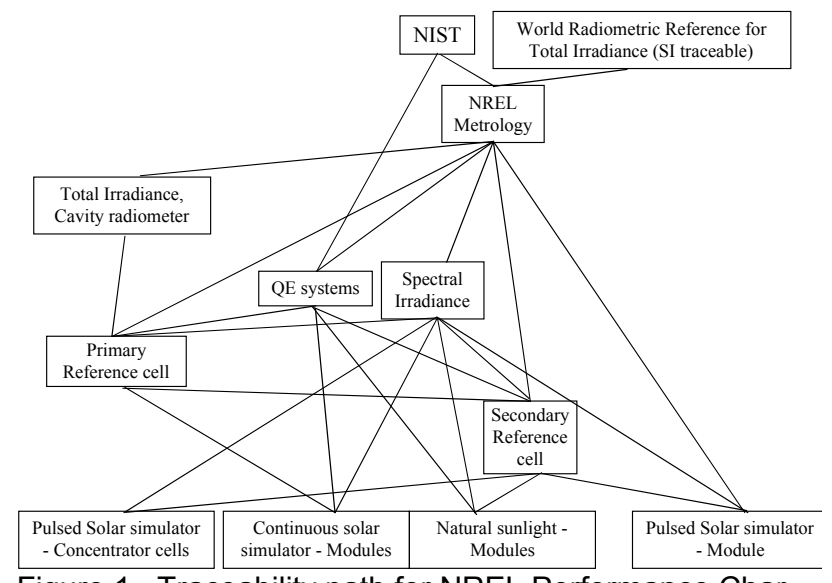

Figure 1. Traceability path for NREL Performance Characterization Group. interval. The custom cell and module current-voltage (I-V) test beds at NREL attempt to use instrumentation that has to drift out of calibration 100 times or more to be at the $1 \%$ level in current or voltage. Other equipment may require periodic functional checks to ensure proper operation. Periodic performance verifications on a test sample are required to ensure that equipment is functioning properly.

We recently had a case where a 4 -wire 1 -ohm resistor with a $0.01 \% /$ year stability, $15 \mathrm{ppm} /{ }^{\circ} \mathrm{C}$ temperature coefficient calibrated to better than $0.02 \%$ drifted by $1.35 \%$ after its annual recalibration. All of our custom test beds incorporate fuses in series with current sense resistors to prevent the current or power from ever approaching the manufacturer rated power. This resistor was fused to blow at $2.3 \mathrm{~W}$, or $7.5 \%$ of the manufacturer-specified resistor power rating. When notified of this out-of-tolerance condition, the calibration value was independently checked with a micro-ohm meter. The resistors are calibrated at their maximum and minimum current calculated by the software. As part of the quality assurance program, this nonconforming condition requires that all customers affected will be notified. The first problem is to determine-by examining previous proficiency checks, intercomparisons, and performance verifications-when in the past year the resistor actually drifted. To date, the results are inconclusive. As a result of lessons learned, all custom test beds now have software checks to ensure that the same current is measured within $0.1 \%$ for adjacent resistors. In our case, we use $100,10,1,0.1,0.01$, and 0.001 precision resistors to cover a range on our various test beds from micro amps to $60 \mathrm{~A}$. On one of our test beds, we have a current source, which is accurate to at least $0.1 \%$, that serves as another check to ensure that this scenario will not occur again. It should be noted that commercial PV test systems typically have no internal checks to see if the current or voltage is significantly out of tolerance between calibrations.

The group measures the cell and module I-V and quantum efficiency (QE) on a variety of commercial and custom test beds. The capabilities of these test beds are summarized in Table 1. Many of these test beds have overlapping voltage, current, and size ranges. This allows the same sample to be tested on multiple test beds. This is critical to prevent a false sense of confidence in the data. Each test bed has its own error sources. The outdoor test bed has the best spatial uniformity, but the worst temperature control. Pulsed measurement systems do not have significant temperature-related errors, but errors related to bias rate or pre-measurement conditions can be significant.

Data acquisition and analysis software has been developed over the years. The process of verifying software written by someone else within the group is an essential part of the quality system. The software platform of LabView developed by National Instruments was chosen for all data acquisition and numerical analysis. The reason for this was that LabView, is transparent between Macintosh and PC operating systems, provides an excellent graphical user interface, allows easy testing sections of code, and enables descriptive variables and good structured programming practices to be followed. This is critical to be able to verify and approve software as required by an ISO 17025 quality system. 
All test beds use standardized subprograms (or vi's, using LabView terminology) for graphical output, spectral error computation, and curve-fitting portions of the I-V data to obtain the short-circuit current, $I_{s c}$, open-circuit voltage, $V_{o c}$, and maximum power point, $P_{\max }$, that are based on algorithms that work for nearly all cell and module technologies measured on all test beds. Most commercial algorithms fail for some cell types because they are not tested on all PV technologies by the manufacturer. At NREL, $I_{s c}$ is determined by performing a linear-regression fit to all I-V points that satisfy the constraint that all currents are within $4 \%$ of the current at $0 \mathrm{~V}$ and all voltages within 0.20 times the voltage at $0 \mathrm{~A}$. $P_{\max }$ is determined by performing a polynomial fit of all I-V points that satisfy the constraints that the measured power be within $85 \%$ of the largest measured power and the voltage is within $80 \%$ of the voltage at the largest measured power. The polynomial that gives the best fit to the data up to a fifth order is used. The voltage at maximum power, $V_{m}$, is the real root of the derivative of the fit of the power versus voltage polynomial set equal to 0 . This voltage is then substituted into a power versus voltage polynomial to obtain the $P_{\max }$.

\section{QUALITY SYSTEM}

ISO 17025 gives minimum guidelines for a quality system [1]. The quality system must include a statement of management's commitment to the quality of its testing and calibrations; objectives of the quality system; documentation of policies, systems, programs, procedures, and instructions to ensure the quality of the results; and roles and responsibilities of technical management for ensuring compliance with the quality system. Other requirements are backup personnel for all functions-including operators, software development, hardware development, calibration, and data review. Documentation of software, hardware, and calibration for all test beds is required. All software, forms, checklists, work instructions, and procedures require version control so that everyone is working off the same version. All data and calibrations must be reviewed by someone who was not involved in the process, but is trained to review the results.

\section{UNCERTAINTY ANALYSIS}

A comprehensive uncertainty analysis following the accepted guide for measurement uncertaintyMeasurement Uncertainty (GUM) of the International Bureau of Weights and Measures-was performed as part of NREL's accreditation [18,19]. The GUM defines Type A uncertainty values as derived from statistical methods, and Type B sources as evaluated by "other means," such as scientific judgment, experience, specifications, comparisons, or calibration data. The GUM defines the concept of a "standard uncertainty" for each uncertainty type, which is an estimate of an "equivalent" standard deviation (of a specified distribution). The GUM replaces the historical factor of 2 with a "coverage factor," $k$ (dependent on the known or assumed statistical distribution of uncertainties), and uncertainty $U$ :

$$
U^{2}=\Sigma(\text { Type } B)^{2}+\Sigma(k \cdot \text { Type } A)^{2}
$$

Uncertainty analysis allows the dominant sources of uncertainty to be identified. For PV applications, the reference device is typically a dominant error source. The spectral correction factor and area measurement can also be significant sources of error. Calibration functional checks, proficiency checks, and performance verifications are supposed to ensure that the maximum percent change in the calibrated value (e.g., efficiency, $I_{s c}, V_{o c}$ ) is below some threshold. ISO 17025 accreditation requires that if calibrations are out of tolerance, then an analysis is required with customer notification if the out-of-tolerance condition is deemed significant.

\section{SUMMARY}

Obtaining ISO 17025 accreditation as a PV cell and module calibration laboratory is insufficient to ensure that the calibration results are valid within uncertainty estimates. The accredited calibration laboratory must verify its results through internal and external intercomparisons. The group that requested the PV calibration should be able to verify that the cell did not change after calibration through dark I-V or other means, and by comparison with other standards calibrated previously. It is generally wise to have at least three stable calibrated reference cells that are recalibrated on an annual basis.

For the health of the PV community, performance measurements on cells and modules performed by researchers or calibration laboratories must be periodically verified by a third party. Groups that perform this on a regular basis establish a level of trust that future measurements will also be within tolerance or expected uncertainty limits.

\section{REFERENCES}

[1] ISO / IEC 17025, General Requirements for the Competence of Testing and Calibration Laboratories, 1999, International Standards Organization, Geneva, Switzerland.

[2] H. Ossenbrink, R. Van Steenwinkel, and K. Krebs, "The Results of the 1984/1985 Round-Robin Calibration of Reference Solar Cells for the Summit Working Group on Technology, Growth and Employment," Joint Research Center, ISPRA Establishment, ISPRA Italy, Tech Rep. EUR 10613 EN (April 1986).

[3] K.A. Emery, C.R. Osterwald, L.L. Kazmerski, and R.E. Hart, "Calibration of Primary Terrestrial References Cells When Compared with Primary AM0 Reference Cells," Proc. 8th European PSEC, 1988, pp. 64-68.

[5] J. Metzdorf, et. al, "The Results of the PEP '87 Round-Robin Calibration of Reference Cells and Modules, Final Report," PTB Technical Report PTB-Opt-31, Braunschweig, Germany, November 1990, ISBN 3-89429067-6, see also 21st IEEE PVSC, 1990, p.95.

[6] C.R. Osterwald, et. al,, "Results of the PEP '93 Intercomparison of Reference Cell Calibrations and Newer Technology Performance Measurements," 25th IEEE PVSC, 1996, pp. 1263-1266. see also March 1998, NREL Tech. Rep. NREL/TP-520-23477.

[7] M.A. Green, K. Emery, D.L. King, S. Igari, and W. Warta, "Solar Cell Efficiency Tables (version 24)" Progress 
in Photovoltaics Research and Applications, 12, 2004, pp. 365-372.

[8] ASTM Standard G159, Standard Tables for References Solar Spectral Irradiance at Air Mass 1.5: Direct Normal and Hemispherical for a $37^{\circ}$ Tilted Surface, Amer. Society for Testing Matls., West Conshocken PA, USA, 1998. See also IEC standard 60904-3.

[9] K. Emery, D. Myers, and S. Kurtz, "What is the Appropriate Reference Spectrum for Characterizing Concentrator Cells?," 29th IEEE, 2002, pp. 840-843.

[10] ASTM Standard G173, Standard Tables for Reference Solar Spectral Irradiances: Direct Normal and Hemispherical on $37^{\circ}$ Tilted Surface, Amer. Society for Testing Matls., West Conshocken PA, USA,2003.

[11] C.R. Osterwald, et. al, "The World Photovoltaic Scale: An International Reference Cell Calibration Program," Progress in PV, 7, pp. 287-297, 1999.

[12] ISO/DIS 15387, Space Systems - Space Solar Cells - Requirement, Measurements and Calibration Procedures, 2003. International Standards Organization, Geneva, Switzerland.

[13] C.A. Gueymard, D. Myers, and K. Emery, "Proposed Reference Irradiance Spectra for Solar Energy Systems Testing," Solar Energy, 73, pp. 443-467, 2002.
[14] K.A. Emery, "Measurement and Characterization of Solar Cells and Modules," Handbook of Photovoltaic Science and Engineering, Chap. 16, pp. 701-747, A. Luque and S. Hegedus, editors, John Wiley \& Sons, W. Sussex, UK, ISBN 0-471-49196-9, 2003.

[15] ASTM Standard E490, Standard Solar Constant and Zero Air Mass Solar Spectral Irradiance Tables, Amer. Society for Testing Matls., West Conshocken, PA, USA, 2000.

[16] D. Brinker, et. al,, "Results from the $1^{\text {st }}$ International AMO Calibration Round Robin of Silicon and GaAs Solar Cells," 3rd World Conference and Exhibition on Photovoltaic Solar Energy Conversion, 2003, paper 3PC342.

[17] K. Emery and H. Field, "Artificial Enhancements and Reductions in the PV Efficiency," Proc. 24th IEEE Photovoltaic Specialists Conf., Waikoloa, HI, Dec.5-9, 1994, pp. 1833-1838, IEEE, New York, 1994.

[18] American Association for Laboratory Accreditation certificate A2LA 2236.01 for Secondary Reference Cell Calibration, Web site: www.a2la.org, Frederick, MD.

[19] Procedure ISO GUM "International Organization for Standardization, Guide to the Expression of Uncertainty in Measurement," ISO: Geneva, 1995, ISBN 92-67-10188-9.

Table 1. Instrumentation for Performance Measurements in the PV Cell and Module Measurement Group at NREL

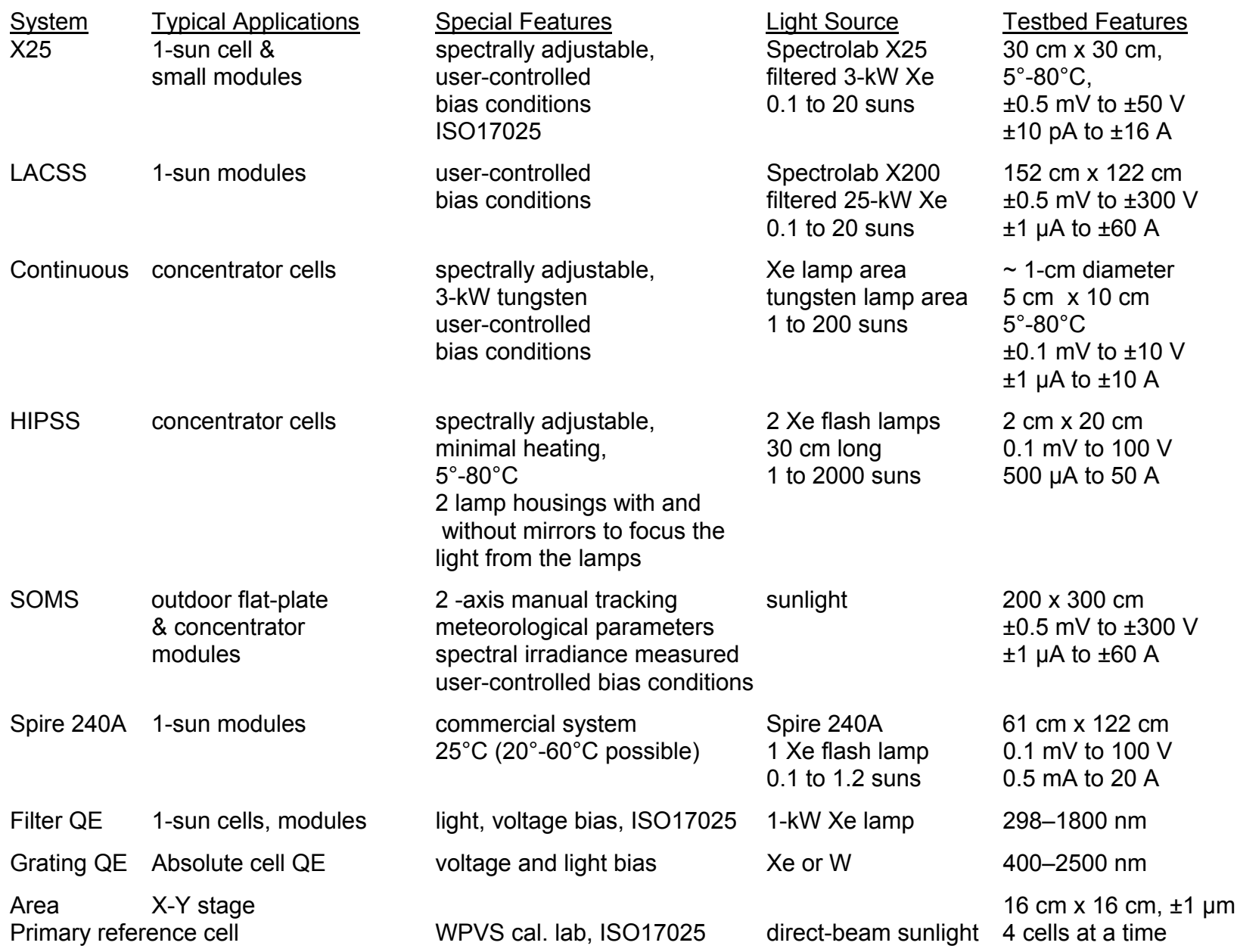




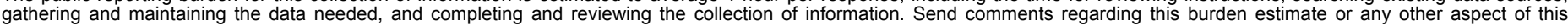

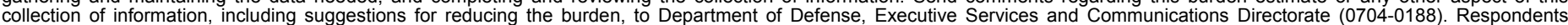

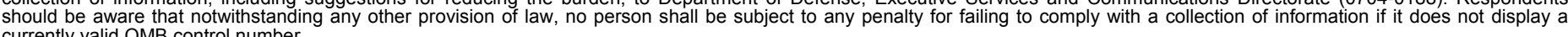

PLEASE DO NOT RETURN YOUR FORM TO THE ABOVE ORGANIZATION.

\begin{tabular}{l|l|l|}
\hline 1. REPORT DATE $(D D-M M-Y Y Y Y)$ & 2. REPORT TYPE & 3. DATES COVERED (FrOm - TO)
\end{tabular}

February 2005

Conference Paper

4. TITLE AND SUBTITLE

Trust But Verify: Procedures to Achieve Accurate Efficiency

Measurements for All Photovoltaic Technologies 5a. CONTRACT NUMBER

DE-AC36-99-GO10337

5b. GRANT NUMBER

5c. PROGRAM ELEMENT NUMBER

5d. PROJECT NUMBER

NREL/CP-520-36527

5e. TASK NUMBER

PVA53401

5f. WORK UNIT NUMBER
7. PERFORMING ORGANIZATION NAME(S) AND ADDRESS(ES)

National Renewable Energy Laboratory

1617 Cole Blvd.

Golden, CO 80401-3393

9. SPONSORING/MONITORING AGENCY NAME(S) AND ADDRESS(ES) 8. PERFORMING ORGANIZATION
REPORT NUMBER

NREL/CP-520-36527
10. SPONSOR/MONITOR'S ACRONYM(S) NREL

11. SPONSORING/MONITORING AGENCY REPORT NUMBER

12. DISTRIBUTION AVAILABILITY STATEMENT

National Technical Information Service

U.S. Department of Commerce

5285 Port Royal Road

Springfield, VA 22161

13. SUPPLEMENTARY NOTES

14. ABSTRACT (Maximum 200 Words)

The measurement of the photovoltaic $(\mathrm{PV})$ performance with respect to reference conditions requires measuring the performance with respect to a given tabular reference spectrum, junction temperature, and total irradiance. This paper discusses the procedures implemented by NREL's PV Cell and Module Performance Characterization Group to achieve the lowest practical uncertainty. This paper describes the process of trusting and verifying software, hardware, calibrations, procedures, and results. As an ISO 17025 accredited calibration facility, the quality system that is in place is designed to assure customers that the results are valid within specified uncertainty limits and are traceable. The process of trusting claims but desiring an independent verification permeates the PV business and society.

15. SUBJECT TERMS

PV; efficiency measurements; performance; tabular reference spectrum; junction temperature; total irradiance; trusting and verifying software;

\begin{tabular}{l}
\hline \multicolumn{1}{|l|}{ 16. SECURITY CLASSIFICATION OF: } \\
\hline \begin{tabular}{l|l|l|} 
a. REPORT & b. ABSTRACT \\
Unclassified & Unclassified & UHIS PAGE \\
& Unclassified
\end{tabular} \\
\hline
\end{tabular}

\begin{tabular}{|l|l|}
$\begin{array}{l}\text { 17. } \\
\text { LIMITATION } \\
\text { OF ABSTRACT } \\
\text { UL }\end{array}$ & $\begin{array}{l}\text { 18. } \\
\text { NUMBER } \\
\text { OF PAGES }\end{array}$ \\
&
\end{tabular}

19a. NAME OF RESPONSIBLE PERSON

19b. TELEPHONE NUMBER (Include area code) 